\title{
Understanding Pharmacist Communication and Medication Errors: A Systematic Literature Review
}

\author{
M Sassoli and G Day
}

\begin{abstract}
Objective: To better understand the inter-professional clinical communication between pharmacists, other health professionals and medication errors.
\end{abstract}

Methods: This research study used a systematic literature review approach by searching online databases including Medline, PubMed and CINHAL to understand the relationship between pharmacist clinical communication and medication errors. The results of this study show that from 1158 studies that were screened and assessed, only 454 studies were initially selected after the application of inclusion and exclusion criteria. A PRISMA chart and descriptive analysis was used to present the result.

Results: The results concluded that of the 18 studies, 17 showed a relationship between communication and medication errors, while only one study indicated no relationship. Thematic synthesis was used to classify the result of the 17 studies. The result was classified into five general themes based on the literature review and similarity among the studies.

\section{Maryam Sassoli}

School of Medicine

Griffith University

Southport, Queensland, Australia.

\section{Gary Day}

School of Medicine

Griffith University

Southport, Queensland, Australia.

Correspondence:

Maryam.sassoli@griffithuni.edu.au
Conclusions: This systematic literature review investigated the interrelationship between communication and medication errors. In regards to patient safety, the research highlights that structured communication is effective in preventing medication errors. These errors can occur within the medication management cycle at any point of the drug distribution chain. This is due to the involvement of different health professionals, and different steps in the cycle from the correct prescription through to correct administration. Thus, to effectively prevent medication errors and reduce the rate of patient harm, structured communication (verbally and non-verbally) is highly recommended.

Abbreviations: GP - General Practitioner; SLR Systematic Literature Review.

Key words: structured communication; health professional communication; medication; safety; pharmacist; medication error.

\section{Literature review}

Medication errors are one of the top ten serious adverse events of medical errors, which directly or indirectly have a negative impact on the quality of care. $[1,2]$

Medication errors are defined as any factors that alter the distribution chain, which includes the prescribing, dispensing, preparation and administration of drugs. [3,4] Medication errors are a common preventable type of error that causes patient harm, unwanted hospitalisation, longer stay in hospital and even fatality. [5] Due to the complexity of the medication process, the contributing factors of medication errors within the hospital are either systematic or related to individual healthcare professional issues. [2,6] Pharmacists play various roles in the healthcare system and 
pharmaceutical care requires the pharmacist's involvement to prevent and solve drug related problems. [7] Additionally, pharmacists help with improving safety of medication use, [8] quality assurance and care services, which can reduce or eliminate the risk of errors. [9] Medication errors can be due to prescribing, dispensing and drug administration errors and related factors to the drug distribution chain. [3, 10-14]

Medication errors issues and factors are significant safety problems in hospitals worldwide. [15-17] Approximately 2-3\% of all admissions to Australian hospitals were medication related errors, which were predominantly caused by systematic rather than individual healthcare professional failure. [18-20]

Each year, over 1.5 million Australians experience adverse drug events. [21] Adverse drug events have been identified as one of the most significant causes of morbidity in Australia. [22] A recent Australian study suggested that medicationrelated incidents accounted for over 230,000 admissions and cost the Australian healthcare system approximately $\$ 1.2$ billion annually. $[18,20]$ Medication errors in Australian hospitals were mainly reported as administration errors based on the ward stock, while dispensing errors were among the least common errors. [23] Medication error contributing factors can be categorised as knowledge-based, rulesbased, action-based and or memory-based. [24] Clinical errors occurred in $20 \%$ to $25 \%$ of medication administration worldwide and are clinically significant within Australian medication error cases. [25,26] Additionally, Queensland Health reported that $27 \%$ of clinical incidents were due to communication failure and a leading contributing factor in staff or practitioner related SAC1 incidents. [27]

Various Australian studies related to medication errors found that $26 \%$ of 27,000 hospital incidents were medication related. [23] The Western Australian Health Clinical Handover Policy aims to achieve effective, high quality communication of clinical information when the responsibility for patient care is transferred. This results in reducing incorrect treatment, delays in diagnosis and treatment, adverse events, length of stay, expenditure, unnecessary tests, treatments and communication, patient complaints and malpractice claims. [28]

Whenever a patient's medication information is communicated, there is a potential for medication errors. [29] Thus, the accuracy of patient current medication information is important as it varies due to patient confusion; inadequate communication between General Practitioners, (GPs) pharmacists and specialists; the degree to which relatives have been informed; and information about drug and dosage gained by informed healthcare workers. [30] Communication in the health sector affects all aspects of human health and it plays a unique role in health services. 'Health communication has become an accepted tool for promoting public health'. [31] The exchanging of information can happen in both verbal and non-verbal forms at various levels. [31-33]

Within the health sector, inter-professional communication regularly involves the interaction of various healthcare professionals. In such diverse fields at various stages of patient treatment, health professionals must work collaboratively together in complementary roles to reduce negative impact on care. Communication is the key to efficient collaboration between and within healthcare teams. [34-39] Issues in communication, especially the transfer of clinical information, have been identified as one of the most important factors in serious adverse events in Australian healthcare settings [40] and about $70 \%$ of medical incidents are caused by communication failure. [41] Inter-professional communication is complex and communication barriers can lead to ineffective communication within interprofessional teams. $[31,42,43]$ The medication management cycle indicates that decisions from appropriate treatment to the transfer of verified information are all based on communication. [24]

A 2006 review of New South Wales public hospitals reported that medication errors occurred in 17,367 incidents. In 968 of these medication incidents, the results were primary and secondary patient harm. [44] In addition, the NSW Health Patient Safety and Clinical Quality Program reported that the major contributing factors causing medical errors were deficiencies in policies (25\%), communication (25\%) and knowledge competency (18\%). [45] The Victorian public health system in 2008-09 and Queensland Health in 2005-06 reported that $20 \%$ of sentinel events were due to communication issues or failures and it was the second most common contributing factor to sentinel events. [46] Furthermore, another Australian study between 20052010 revealed that reported medication errors were caused by poor communication between GPs, pharmacists and patients (8.7\%), and poor staff communication and coordination (9.6\%). [47] The Queensland Health Patient Safety Report of 2005-06 indicated that medication incidents were one of the top five primary clinical incidents (21\%). Of these medication incidents, communication was one of the top five contributing factors to sentinel events (20\%) and it emphasised that staff to staff communication failure 
was one of the top five sub-category contributing factors (13.7\%). [48] However, by comparison, the Queensland Health Patient Safety Report of 2006-07 showed a reduction in medication incidents (12\%) where $11 \%$ were caused by staff to staff communication failure. [49] Therefore, it could be suggested that there is a direct relationship between communication and medication incidents.

Various clinical strategies have been designed to reduce medical incidents and improve patient safety. The SBAR verbal communication framework is one of the strategies that have been introduced into health communication aimed at preventing medical incidents. [50] The SBAR communication model provides a framework to enable individuals with basic communication skills to accurately share information about the patient's current condition. [51] The SBAR verbal communication framework has been implemented and adapted in various countries such as Canada, America and United Kingdom hospitals. [52-54] The SBAR tool brought changes to communication processes and improved patient safety outcomes, teamwork and overall satisfaction of nurses, physicians, staff and patients. [35, 55-57] Expanded SBAR (or ISBAR or iSoBAR) is now being used across Australia to encompass the transfer of accountability and responsibility required at handover with the Australian Commission on Safety and Quality in Healthcare recommending the SBAR communication toolkit as a simple solution for most communication related issues. [40]

Despite all of the various studies that indicated the relationship between medication errors and communication, there was a paucity of literature to define interprofessional communication between pharmacists and other health professionals, medication errors and structured clinical communication. Additionally, the literature failed to identify studies that addressed structured communication and a reduction in medication error rates.

The study aims to find if a relationship exist between the communication among different health team members (particularly pharmacists and other health team members) and medication errors in different studies, and; does structured communication reduced the medication errors rate?

\section{Research design and methods}

The systematic literature review (SLR) process is commonly used in the field of healthcare and in this study the SLR was used to identify the relationship between medication errors and health communication, specifically to find whether implemented structured communication reduces medication errors. PICO elements (Participants, Intervention, Comparators and Outcomes) were used for the question revision:

- Participants were considered to be all health professionals who communicate medication therapy within the drug distribution process in all medical fields;

- Intervention was the structured communication among health professional specifically pharmacists;

- Comparator considered any structured communication in written or verbal for mat and medication safety verses poor communication and medication errors; and

- Outcomes identified whether structured communication reduced medication errors rates and if there is any relationship between communication and medication safety.

A list of exclusion and inclusion criteria was generated according to the key questions, (Table 1).Studies were limited to those with outcomes and factors related to structured communication and reduced numbers of medication errors. Medication errors and health communication were defined according to previous studies and, to ensure that studies that were reviewed were relevant to current world practice, published English-language academic journal articles between the years 2000-2015 were chosen.

The inclusion criteria such as study population, study settings and geography, language, time period and publication criteria were considered prior to data extraction. In terms of the selection of suitable articles, four phases of the developed research's strategy such as identification, screening, eligibility and including phase were applied.

Using the key words 'health professional communication' and 'medication errors', 'structured communication' and 'medication errors', 'structured communication' and 'medication safety' and 'pharmacist', an electronic search of databases including CINHAL, PubMed and Medline was undertaken. A large number of potentially eligible records were assessed for inclusion against predetermined criteria. As the potential to duplicate the same article from multiple databases is inevitable, EndNote software was used to remove duplicates automatically to reduce biases. In the screening phase, the inclusion criteria was applied to the title and abstract of each study that was found during searching process. Additionally, a note taking strategy was used and the studies fulfilling the inclusion criteria were saved separately in a specific document. 
Table 1: Inclusion and exclusion criteria of the study

\begin{tabular}{|l|l|}
\hline INCLUSION CRITERIA & EXCLUSION CRITERIA \\
\hline $\begin{array}{l}\text { Study population: } \\
\begin{array}{l}\text { All health professionals involved in patient } \\
\text { pharmaceutical therapy }\end{array}\end{array}$ & $\begin{array}{l}\text { Study population: } \\
\text { All patient related studies are not linked to health } \\
\text { professionals }\end{array}$ \\
\hline $\begin{array}{l}\text { Study settings: } \\
\text { Studies conducted in the developed world including } \\
\text { the United States, Australia, New Zealand and Europe }\end{array}$ & $\begin{array}{l}\text { Study settings: } \\
\text { Developing countries }\end{array}$ \\
\hline $\begin{array}{l}\text { Time period: } \\
\text { 200 } \\
0- \\
201\end{array}$ & $\begin{array}{l}\text { Time period: } \\
\text { Before } \\
2000 \\
0\end{array}$ \\
\hline $\begin{array}{l}\text { Language: } \\
\text { English }\end{array}$ & $\begin{array}{l}\text { Language: } \\
\text { Non-English }\end{array}$ \\
\hline $\begin{array}{l}\text { Publication Criteria: } \\
\text { Peer reviewed } \\
\text { Academic Journal article } \\
\text { Full text and abstraction availability }\end{array}$ & $\begin{array}{l}\text { Publication Criteria: } \\
\text { Peer reviewed paper }\end{array}$ \\
\hline
\end{tabular}

For eligibility purposes, the inclusion criteria were applied specifically the contents of each selected paper from the screening phase to determine their accuracy. In the inclusion phase, the final decision for included articles was made based on a close assessment of each paper's contents and the application of the inclusion criteria using the PRISMA flow chart to report the selected study decision. The checklist used for the quality assessment of the selected papers, specifically, the Greenfield and Pawsey [58] quality assessment tool, was used to examine the quality based on appropriateness of the research question, research design and justification, relevance of methodology, analysis of results, and logical presentation of the research (Table 2).

A data extraction process was used to provide an overview of all the data from included and selected studies. A data extraction form was designed based on the general information (author, article title, type of publication, year and setting), study characteristics (objective, study

Table 2: Assessment criteria adapted from Greenfield, Pawsey [58] study

\begin{tabular}{|c|c|}
\hline FOR ALL STUDIES & ASSESSMENT CRITERIA \\
\hline & $\begin{array}{l}\text { Clearly specified and appropriate research question } \\
\text { Clear details and justification of study design, including selection of cases and controls } \\
\text { Detailed description of research setting, data collection methods and type of analysis } \\
\text { performed } \\
\text { Logical presentation and discussion of results and study conclusion } \\
\text { Adequate sample size and response rate }(>60 \%) \text { relative to study }\end{array}$ \\
\hline OVERALL RATINGS & ASSESSMENT CRITERIA \\
\hline+++ & All of the above criteria fulfilled \\
\hline++ & $\begin{array}{l}\text { Almost all of the above criteria fulfilled, and those criteria that were not fulfilled were } \\
\text { thought unlikely to alter the conclusions of the study }\end{array}$ \\
\hline+ & $\begin{array}{l}\text { Some of the criteria were fulfilled, and those criteria that were not fulfilled were though } \\
\text { unlikely to alter the conclusions of the study }\end{array}$ \\
\hline
\end{tabular}


design and unit of allocation), participant characteristics, settings, outcome measurement and results. [59] Accuracy andconsistency of data entry was controlled and monitored through revision by two independent researchers on the data extraction and data entry process.

\section{Results}

The initial search identified a total of 1158 citations. After scanning citation titles, 454 were selected for further screening and their complete abstract and content were reviewed. Of these, only 18 studies were eligible to be included in the systematic review. Thirteen studies were excluded because these papers were not peer reviewed, or were unrelated to health communication, medication errors (multi-dose dispensing system, team management com- munication and medication reconciliation rate) or explored the patient safety guidelines with the lack of research outcomes. The PRISMA flow chart (Figure1) was used to summarise the result of data extraction after the inclusion and exclusion criteria stage and to show the final selection result.

The quality assessment criteria were critically applied to the 18 studies and the result showed that seven studies fulfilled the all assessment criteria with +++ ratings and ten studies fulfilled almost all the criteria and failed in one to two criteria and were thought unlikely to alter the conclusions of the study. A summary of the quality assessment results can be seen in Table 3.

\section{Figure 1: PRISMA Chart}

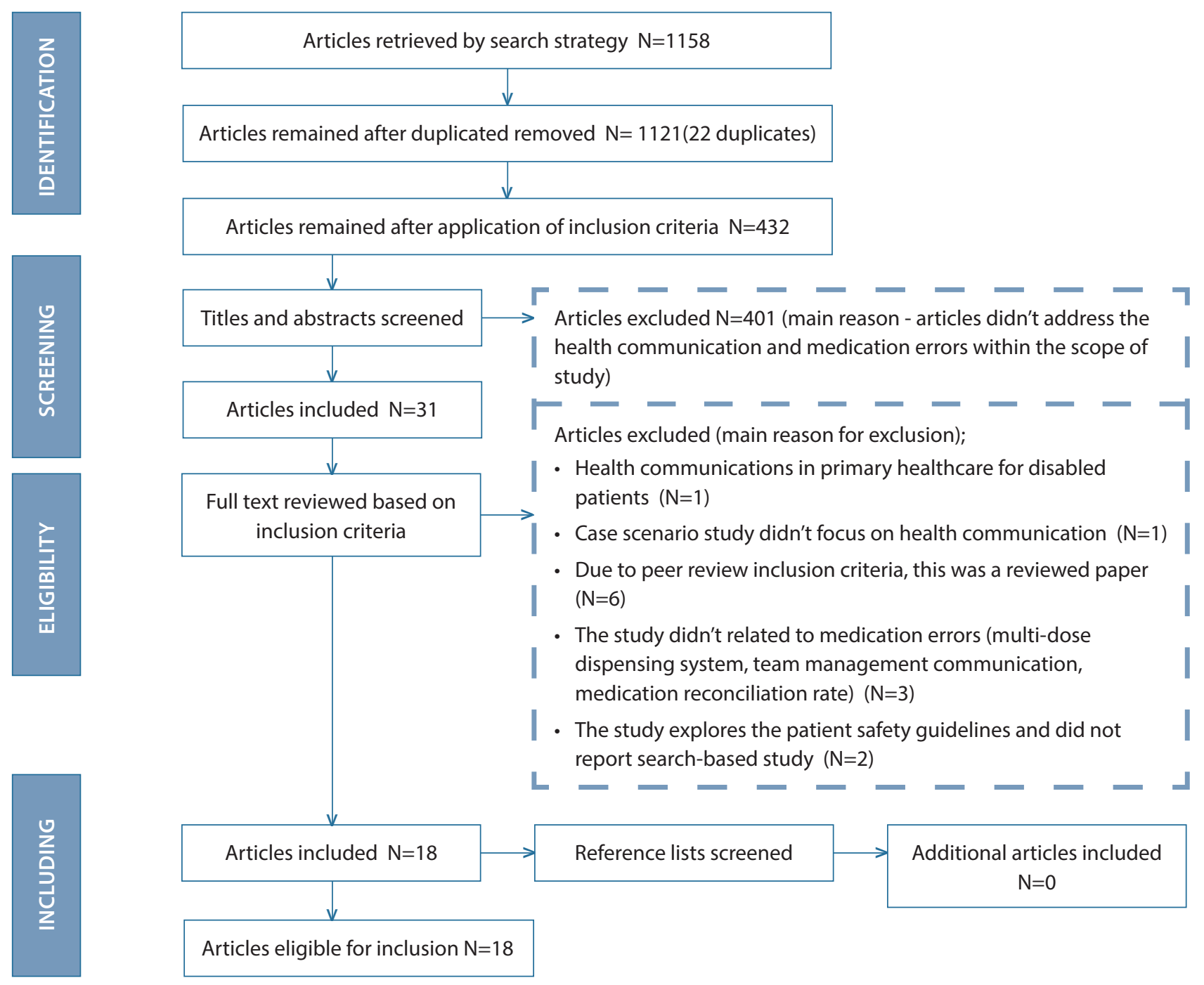


Table 3: The quality assessment results

\begin{tabular}{|c|c|c|c|c|}
\hline NO & AUTHOR & THE STUDY TITLE & $\begin{array}{l}\text { JOURNAL } \\
\text { NAME }\end{array}$ & $\begin{array}{l}\text { QUALITY RATING } \\
\text { ACCORDING TO } \\
\text { GREENFIELD ET AL }\end{array}$ \\
\hline 1 & {$[60]$} & $\begin{array}{l}\text { Poor communication on patients' medication across healthcare } \\
\text { levels leads to potentially harmful medication errors. }\end{array}$ & $\begin{array}{l}\text { Scandinavian } \\
\text { Journal of } \\
\text { Primary } \\
\text { Healthcare }\end{array}$ & +++ \\
\hline 2 & [61] & $\begin{array}{l}\text { Do you believe your patients are reasonably safe from } \\
\text { medication errors, falls, and other adverse events? Compare } \\
\text { your opinions and observations to those of nearly 5,000 nurses } \\
\text { who responded to this major safety survey. }\end{array}$ & Nursing 2006 & ++ \\
\hline 3 & {$[62]$} & $\begin{array}{l}\text { To illustrate variety of medication errors in the emergency } \\
\text { department. }\end{array}$ & $\begin{array}{l}\text { Academic } \\
\text { Emergency } \\
\text { Medicine }\end{array}$ & ++ \\
\hline 4 & {$[63]$} & Bedside nursing handover: a case study. & $\begin{array}{l}\text { International } \\
\text { Journal of } \\
\text { Nursing Practice }\end{array}$ & +++ \\
\hline 5 & [64] & $\begin{array}{l}\text { Healthy work environments, nurse-physician communication, } \\
\text { and patients' outcomes. }\end{array}$ & $\begin{array}{l}\text { American } \\
\text { Journal of } \\
\text { Critical Care }\end{array}$ & ++ \\
\hline 6 & {$[65]$} & Drug error in maternity care: a multi-professional issue & $\begin{array}{l}\text { British } \\
\text { Journal of } \\
\text { Midwifery }\end{array}$ & ++ \\
\hline 7 & {$[66]$} & $\begin{array}{l}\text { Collaboration - integrating nursing, pharmacy and information } \\
\text { technology into a barcode medication administration system } \\
\text { implementation. }\end{array}$ & CARING & +++ \\
\hline 8 & [67] & $\begin{array}{l}\text { Communication skills training to address disruptive physician } \\
\text { behaviour. }\end{array}$ & $\begin{array}{l}\text { AORN } \\
\text { (Association } \\
\text { of Perioperative } \\
\text { Nurse) Journal }\end{array}$ & ++ \\
\hline 9 & {$[68]$} & Applying airline safety practices to medication administration. & $\begin{array}{l}\text { Academy of } \\
\text { Medical-Surgical } \\
\text { Nurses }\end{array}$ & +++ \\
\hline 10 & [69] & $\begin{array}{l}\text { Barriers to safe medication administration in the nursing } \\
\text { home-exploring staff perceptions and concerns about the } \\
\text { medication use process. }\end{array}$ & $\begin{array}{l}\text { Journal of } \\
\text { Gerontological } \\
\text { Nursing }\end{array}$ & ++ \\
\hline 11 & {$[70]$} & Antecedents of severe and non-severe medication errors. & $\begin{array}{l}\text { Journal of } \\
\text { Nursing } \\
\text { Scholarship }\end{array}$ & ++ \\
\hline 12 & [71] & $\begin{array}{l}\text { A secondary care nursing perspective on medication } \\
\text { administration safety }\end{array}$ & $\begin{array}{l}\text { Journal of } \\
\text { Advanced } \\
\text { Nursing }\end{array}$ & +++ \\
\hline 13 & {$[72]$} & $\begin{array}{l}\text { Reflection and analysis of how pharmacy students learn } \\
\text { to communicate about medication errors }\end{array}$ & $\begin{array}{l}\text { Health } \\
\text { Communication }\end{array}$ & ++ \\
\hline 14 & [73] & $\begin{array}{l}\text { Reducing medication errors and increasing patient safety: } \\
\text { case studies in clinical pharmacology }\end{array}$ & $\begin{array}{l}\text { The Journal } \\
\text { of Clinical } \\
\text { Pharmacology }\end{array}$ & ++ \\
\hline
\end{tabular}


Table 3: The quality assessment results

\begin{tabular}{|c|l|l|l|l|}
\hline NO & AUTHOR & THE STUDY TITLE & $\begin{array}{l}\text { JOURNAL } \\
\text { NAME }\end{array}$ & $\begin{array}{l}\text { QUALITY RATING } \\
\text { ACCORDING TO } \\
\text { GREENFIELD ET AL }\end{array}$ \\
\hline 14 & {$[73]$} & $\begin{array}{l}\text { Reducing medication errors and increasing patient safety: } \\
\text { case studies in clinical pharmacology. }\end{array}$ & $\begin{array}{l}\text { The Journal } \\
\text { of Clinical } \\
\text { Pharmacology }\end{array}$ & ++ \\
\hline 15 & {$[74]$} & $\begin{array}{l}\text { Comparison of medication safety effectiveness among nine } \\
\text { critical access hospitals. }\end{array}$ & $\begin{array}{l}\text { American } \\
\text { Journal of } \\
\text { Health System } \\
\text { Pharmacy }\end{array}$ & +++ \\
\hline 16 & {$[75]$} & $\begin{array}{l}\text { Errors in general practice: development of an error } \\
\text { classification and pilot study of a method for detecting errors. }\end{array}$ & $\begin{array}{l}\text { Quality and } \\
\text { Safety in } \\
\text { Healthcare }\end{array}$ & ++ \\
\hline 17 & {$[76]$} & $\begin{array}{l}\text { Communicating medication changes to community pharmacy } \\
\text { post-discharge: the good, the bad, and the improvements. }\end{array}$ & $\begin{array}{l}\text { International } \\
\text { Journal of } \\
\text { Clinical } \\
\text { Pharmacy }\end{array}$ & +++ \\
\hline 18 & {$[77]$} & $\begin{array}{l}\text { Pharmacists' inter-professional communication about } \\
\text { medications in specialty hospital settings. }\end{array}$ & $\begin{array}{l}\text { Routledge } \\
\text { Taylor \& } \\
\text { Francis Group }\end{array}$ & +++ \\
\hline
\end{tabular}

Table 4: Data extraction result from the data extraction results

\begin{tabular}{|c|c|c|c|c|c|c|c|c|c|c|}
\hline REF NO & $\begin{array}{l}\text { AUTHOR/ } \\
\text { YEAR }\end{array}$ & TITLE & COUNTRY & $\begin{array}{l}\text { PUBLICATION } \\
\text { TYPE }\end{array}$ & OBJECTIVE & OUTCOME MEASURES & DESIGN & PARTICIPANTS & RESULTS & $\begin{array}{l}\text { STUDY } \\
\text { LIMITATION }\end{array}$ \\
\hline 7 & [66] & $\begin{array}{l}\text { Collaboration - } \\
\text { Integrating Nursing, } \\
\text { Pharmacy and } \\
\text { Information } \\
\text { Technology into a } \\
\text { Barcode Medication } \\
\text { Administration System } \\
\text { Implementation. }\end{array}$ & $\begin{array}{l}\text { United } \\
\text { States. }\end{array}$ & Journal. & $\begin{array}{l}\text { To reduce } \\
\text { medication } \\
\text { errors when } \\
\text { ordering/ } \\
\text { transcribing } \\
\text { medication. } \\
\text { To standardise } \\
\text { medication } \\
\text { administration } \\
\text { practices. } \\
\text { To bring } \\
\text { administration } \\
\text { documentation } \\
\text { to the point } \\
\text { of care. }\end{array}$ & $\begin{array}{l}\text { This study used three } \\
\text { phases of unfreezing, } \\
\text { moving and refreezing } \\
\text { of Kurt Lewin } \\
\text { organisational change } \\
\text { model and named it } \\
\text { as project origination, } \\
\text { workflow redesign } \\
\text { and implementati } \\
\text { on/acceptance/ } \\
\text { integration. } \\
\text { In this study a lot } \\
\text { of various commun- } \\
\text { ications is used with } \\
\text { different carts, } \\
\text { evaluation rating, } \\
\text { meeting, guidelines } \\
\text { to identify potential } \\
\text { issues with implement- } \\
\text { ation of new system. }\end{array}$ & Qualitative. & $\begin{array}{l}365 \text { bed } \\
\text { hospital, } \\
\text { implemented } \\
\text { a Barcode } \\
\text { Medication } \\
\text { Administration } \\
\text { system. }\end{array}$ & $\begin{array}{l}\text { Barcode implement- } \\
\text { ation caused dramatic } \\
\text { increase in the reported } \\
\text { prevented or near-miss } \\
\text { medication error. } \\
\text { It prevents from over } \\
700 \text { (average) medication } \\
\text { errors per month that } \\
\text { could cause real harm } \\
\text { to patients. } \\
\text { It helped to identify } \\
\text { the total scope of } \\
\text { potential errors and } \\
\text { near misses. }\end{array}$ & $\begin{array}{l}\text { This study } \\
\text { did not } \\
\text { mention } \\
\text { any } \\
\text { limitations. }\end{array}$ \\
\hline
\end{tabular}


Table 4: Data extraction result from the data extraction results continued

\begin{tabular}{|c|c|c|c|c|c|c|c|c|c|c|}
\hline REF NO & $\begin{array}{l}\text { AUTHOR/ } \\
\text { YEAR }\end{array}$ & TITLE & COUNTRY & $\begin{array}{l}\text { PUBLICATION } \\
\text { TYPE }\end{array}$ & OBJECTIVE & OUTCOME MEASURES & DESIGN & PARTICIPANTS & RESULTS & $\begin{array}{l}\text { STUDY } \\
\text { LIMITATION }\end{array}$ \\
\hline 13 & [72] & $\begin{array}{l}\text { Reflection and analysis } \\
\text { of how pharmacy } \\
\text { students learn to } \\
\text { communicate about } \\
\text { medication errors. }\end{array}$ & UK. & Journal. & $\begin{array}{l}\text { To examine } \\
\text { how pharmacy } \\
\text { students are } \\
\text { socialised to } \\
\text { apply commu- } \\
\text { nication } \\
\text { strategies when } \\
\text { responding to } \\
\text { potential } \\
\text { medication } \\
\text { errors and their } \\
\text { prevention. }\end{array}$ & $\begin{array}{l}30 \text { min to } 2 \text { hours face } \\
\text { to face interviews of } \\
28 \text { questions on topics } \\
\text { such as memorable } \\
\text { communication- } \\
\text { related medication } \\
\text { errors, reflections on } \\
\text { medication errors } \\
\text { made, and training } \\
\text { on how to handle } \\
\text { medication errors. }\end{array}$ & Qualitative. & $\begin{array}{l}44 \text { participants } \\
\text { who enrolled } \\
\text { in a 6-year } \\
\text { entry level } \\
\text { pharmacy } \\
\text { program and } \\
\text { had completed } \\
\text { at least one } \\
\text { rotation (a } \\
\text { period of } 4 \\
\text { months). } \\
33 \text { female and } \\
11 \text { male } \\
\text { participants. }\end{array}$ & $\begin{array}{l}\text { The thematic analysis } \\
\text { results showed five main } \\
\text { themes regarding } \\
\text { medication errors and } \\
\text { communication that } \\
\text { address the nature and } \\
\text { extent to which pharm- } \\
\text { acy students are social- } \\
\text { ised to communicate } \\
\text { about medication errors, } \\
\text { and the role of commun- } \\
\text { ication in medication } \\
\text { errors. } \\
\text { These five themes were; } \\
\text { pressure to be perfect, } \\
\text { feeling comfortable } \\
\text { talking about mistakes, } \\
\text { assuming and commun- } \\
\text { icating responsibility for } \\
\text { error, learning how } \\
\text { processes can contribute } \\
\text { to errors and their } \\
\text { prevention, and } \\
\text { inadequate and incon- } \\
\text { sistent training on how } \\
\text { to handle medication } \\
\text { errors. }\end{array}$ & $\begin{array}{l}\text { All the } \\
\text { participants } \\
\text { were from } \\
\text { the same } \\
\text { school. } \\
\text { The principal } \\
\text { investigator } \\
\text { could not ask } \\
\text { important } \\
\text { follow up } \\
\text { questions } \\
\text { as the } \\
\text { researcher } \\
\text { student was } \\
\text { asked to do } \\
\text { interviews. } \\
\text { The more } \\
\text { specific } \\
\text { questions } \\
\text { about the } \\
\text { role of } \\
\text { disclosure } \\
\text { in medic- } \\
\text { ation errors } \\
\text { should } \\
\text { be asked } \\
\text { rather than } \\
\text { the general } \\
\text { questions. }\end{array}$ \\
\hline 14 & [73] & $\begin{array}{l}\text { Reducing medication } \\
\text { errors and increasing } \\
\text { patient safety: case } \\
\text { studies in clinical } \\
\text { pharmacology. }\end{array}$ & $\begin{array}{l}\text { United } \\
\text { States }\end{array}$ & Journal. & $\begin{array}{l}\text { To summarise } \\
\text { current known } \\
\text { medication } \\
\text { errors and } \\
\text { translate the } \\
\text { information into } \\
\text { case studies } \\
\text { illustrating } \\
\text { common } \\
\text { scenarios } \\
\text { leading to } \\
\text { medication } \\
\text { errors. }\end{array}$ & $\begin{array}{l}\text { Each case was analysed } \\
\text { to provide insight into } \\
\text { how the medication } \\
\text { error could have been } \\
\text { prevented. } \\
\text { For this reason, the } \\
\text { system errors are } \\
\text { described and the } \\
\text { application of failure } \\
\text { mode effect analysis is } \\
\text { presented to determine } \\
\text { the part of the'safety } \\
\text { net' that failed. }\end{array}$ & Qualitative. & $\begin{array}{l}7 \text { representative } \\
\text { cases from } \\
\text { clinical pharm- } \\
\text { acology, which } \\
\text { failed and led } \\
\text { to medication } \\
\text { errors. }\end{array}$ & $\begin{array}{l}\text { Case1: Communication } \\
\text { problems. } \\
\text { Case 2: Origin of the } \\
\text { informed consent } \\
\text { doctrine. } \\
\text { Case 3: Instruct patients } \\
\text { to call when anything } \\
\text { unusual or unexpected } \\
\text { occurs (provide the } \\
\text { patient with the } \\
\text { information that he/she } \\
\text { would want to know if } \\
\text { receiving the medication). } \\
\text { Case4: Regarding the use } \\
\text { of zeros in written } \\
\text { prescriptions: always lead } \\
\text { and never follow. Poor } \\
\text { communication in the } \\
\text { form of illegible } \\
\text { medication orders, } \\
\text { prescription-writing } \\
\text { errors to correct. } \\
\text { Case 5: Indicated that up } \\
\text { to half of all medication } \\
\text { errors arise from physi- } \\
\text { cian orders, (occurrence } \\
\text { of medication errors in } \\
\text { hospitalised patients: } \\
\text { physician ordering = } \\
39-49 \% \text {, nursing } \\
\text { administration = } \\
26-38 \% \text {, transcription } \\
=11-12 \%, \text { pharmacy } \\
\text { dispensing = } 11-14 \% \text { ), } \\
\text { also inadequate monit- } \\
\text { oring is frequently } \\
\text { included. }\end{array}$ & $\begin{array}{l}\text { This study } \\
\text { did not } \\
\text { mention any } \\
\text { limitations. }\end{array}$ \\
\hline
\end{tabular}


Table 4: Data extraction result from the data extraction results continued

\begin{tabular}{|c|c|c|c|c|c|c|c|c|c|c|}
\hline REF NO & $\begin{array}{l}\text { AUTHOR/ } \\
\text { YEAR }\end{array}$ & TITLE & COUNTRY & $\begin{array}{l}\text { PUBLICATION } \\
\text { TYPE }\end{array}$ & OBJECTIVE & OUTCOME MEASURES & DESIGN & PARTICIPANTS & RESULTS & $\begin{array}{l}\text { STUDY } \\
\text { LIMITATION }\end{array}$ \\
\hline & & & & & & & & & $\begin{array}{l}\text { Case 6: High alert medic- } \\
\text { ation and patient safety, } \\
\text { pharmacological criteria } \\
\text { for identifying high risk } \\
\text { drugs. } \\
\text { Case 7: System errors } \\
\text { leads to medication } \\
\text { errors. This study did not } \\
\text { mention any limitations. }\end{array}$ & \\
\hline 17 & [76] & $\begin{array}{l}\text { Communicating } \\
\text { medication changes } \\
\text { to community pharm- } \\
\text { acy postdischarge: the } \\
\text { good, the bad, and the } \\
\text { improvements. }\end{array}$ & UK. & Journal. & $\begin{array}{l}\text { To establish the } \\
\text { extent to which } \\
\text { community } \\
\text { pharmacies } \\
\text { currently receive } \\
\text { discharge medic- } \\
\text { ation inform- } \\
\text { ation, and for } \\
\text { which patients. } \\
\text { To determine } \\
\text { community } \\
\text { pharmacy staff } \\
\text { opinion on } \\
\text { where and how } \\
\text { current com- } \\
\text { munication } \\
\text { practice could } \\
\text { be improved. }\end{array}$ & $\begin{array}{l}\text { Reported receipt of } \\
\text { discharge medication } \\
\text { information from } \\
\text { hospitals and general } \\
\text { practices. }\end{array}$ & Qualitative. & $\begin{array}{l}14 \text { community } \\
\text { pharmacies. }\end{array}$ & $\begin{array}{l}\text { Receiving information: } \\
\text { community pharmacists } \\
\text { reported that the receipt } \\
\text { of information regarding } \\
\text { medication change was } \\
\text { inconsistent and once } \\
\text { they received patient } \\
\text { discharge medication } \\
\text { summary, it was helpful } \\
\text { and informative. Also, } \\
\text { pharmacists described } \\
\text { lack of standardisation, } \\
\text { and differences in quality } \\
\text { and frequency of } \\
\text { communication that } \\
\text { they received from } \\
\text { individual hospital } \\
\text { trusts and between } \\
\text { hospitals trusts. } \\
\text { Pharmacists regularly did } \\
\text { not receive information } \\
\text { from hospital. Lack of } \\
\text { standardised processes } \\
\text { for the receipt of inform- } \\
\text { ation within the pharm- } \\
\text { acy was another related } \\
\text { problem to this study } \\
\text { and mainly the pharm- } \\
\text { acists felt that the } \\
\text { consequence of poor } \\
\text { communication could be } \\
\text { fatal and lead to patient } \\
\text { harm. The main suggest- } \\
\text { ion from pharmacy staff } \\
\text { to improve current com- } \\
\text { munication was for both } \\
\text { hospital and medical } \\
\text { practices to provide } \\
\text { information more } \\
\text { routinely, using standard- } \\
\text { ised processes and } \\
\text { encourage the widespread } \\
\text { use of the limitation of } \\
\text { this study was interview- } \\
\text { ing of participants during } \\
\text { opening hours and the } \\
\text { interrupted interview to } \\
\text { serve customers. There } \\
\text { were distractions during } \\
\text { the interview. }\end{array}$ & $\begin{array}{l}\text { The limit- } \\
\text { ation of this } \\
\text { study was } \\
\text { interviewing } \\
\text { of particip- } \\
\text { ants during } \\
\text { opening } \\
\text { hours and } \\
\text { the particip- } \\
\text { ants having } \\
\text { an interrupt- } \\
\text { ed interview } \\
\text { to serve } \\
\text { customers. } \\
\text { There were } \\
\text { distractions } \\
\text { during the } \\
\text { interview. }\end{array}$ \\
\hline
\end{tabular}


Table 4: Data extraction result from the data extraction results continued

\begin{tabular}{|c|c|c|c|c|c|c|c|c|c|c|}
\hline REF NO & $\begin{array}{l}\text { AUTHOR/ } \\
\text { YEAR }\end{array}$ & TITLE & COUNTRY & $\begin{array}{l}\text { PUBLICATION } \\
\text { TYPE }\end{array}$ & OBJECTIVE & OUTCOME MEASURES & DESIGN & PARTICIPANTS & RESULTS & $\begin{array}{l}\text { STUDY } \\
\text { LIMITATION }\end{array}$ \\
\hline 17 & [77] & $\begin{array}{l}\text { Pharmacists'inter- } \\
\text { professional com- } \\
\text { munication about } \\
\text { medications in } \\
\text { specialty hospital } \\
\text { settings. }\end{array}$ & Australia. & Journal. & $\begin{array}{l}\text { What is the } \\
\text { nature of the } \\
\text { communication } \\
\text { about medic- } \\
\text { ation between } \\
\text { hospital pharm- } \\
\text { acist and health } \\
\text { professionals } \\
\text { from other } \\
\text { discipline groups } \\
\text { in specialty hos- } \\
\text { pital settings? }\end{array}$ & $\begin{array}{l}\text { Semi structured } \\
\text { interviews with and } \\
\text { the participant } \\
\text { observations at } \\
\text { different level of } \\
\text { communication in the } \\
\text { specialty hospital of } \\
\text { Victoria. }\end{array}$ & Qualitative. & $\begin{array}{l}\text { Pharmacists, } \\
\text { nurses, and } \\
\text { doctors. }\end{array}$ & $\begin{array}{l}\text { Thematic analysis of the } \\
\text { data showed four themes: } \\
\text { - Task focused interprof- } \\
\text { essional communication } \\
\text { - Little interprofessional } \\
\text { collaboration } \\
\text { - Interprofessional } \\
\text { asymmetries in } \\
\text { behaviour, knowledge } \\
\text { and attitudes } \\
\text { - Lesser visibility of } \\
\text { clinical pharmcy }\end{array}$ & $\begin{array}{l}\text { Only one } \\
\text { metropolitan } \\
\text { hospital } \\
\text { participated } \\
\text { in this study } \\
\text { and the data } \\
\text { might not be } \\
\text { transferable } \\
\text { to other } \\
\text { hospitals. } \\
\text { Observations } \\
\text { were not } \\
\text { conducted in } \\
\text { perioperative } \\
\text { care setting } \\
\text { and it is } \\
\text { possible that } \\
\text { one or more } \\
\text { new themes } \\
\text { could have } \\
\text { emerged in } \\
\text { this setting. }\end{array}$ \\
\hline
\end{tabular}

Note: The complete data extraction's table is available on request from the authors.

\section{Discussion}

The results showed that of the 18 studies, 17 showed a relationship between communication and mediation errors, while only one study indicated that there was no relationship. Thematic synthesis was used due to nature of the research (qualitative) to identify patterned meaning across a database and to classify the results of the 18 studies. The themes were synthesised after a line-by-line coding of the included studies. The organisation of these codes into related areas helped to construct descriptive themes and finally, the development of analytical themes. [78]

The results of the studies were classified into five general themes based on the literature review and similarity among of the studies. These themes included:

- Relationship between medication error and communication;

- Structured communication and patient safety;

- Medication communication management cycle;

- Health professional communication education; and

- Pharmacist views about me dication errors.

\section{Relationship between medication error and communication}

Five studies pointed directly or indirectly to a relationship between communication and medication errors at different stages of providing care to patients. [60-62, 64,75]
The application of a communication definition [31,32] to these studies indicates that failure in the transmission of clinical information from one healthcare provider to another has the potential for medication errors. [40] Nurses identified a breakdown in communication as the most significant factor related to medication error and failure in the exchanging of medication information (inadequate communication) within an interdisciplinary team leading to patient harm and medication error. [61] Similarly, research showed that the main cause of medication errors was prescription errors (42\%) and poor communication (30\%). [75] In addition, the critical evaluation of one case study indicated that the main issues were related to the medication communication process in the drug distribution chain. Furthermore, various strategies that were recommended to prevent medication errors in an emergency department were mainly focused on communication and exchanging of clinical information among various healthcare providers. [62] The relationship between medication errors and communication was supported as the study result showed that nurse-physician communication has an impact on medication errors. [64] In this context, it is believed that insufficient information, faulty exchanges of existing information, or ambiguous and unclear information as a part of poor communication lead to medical incidents. [79] According to the findings in these five studies, the researchers agreed that there is a strong relationship between the communication process and drug 
distribution chain, with failure of communication during medication management playing a key role in medication error.

\section{Structured communication and patient safety}

Structured communication is one of the recommended solutions to prevent medical incidents and medication errors. $[38,80]$ In this context, different pathways, guidelines, technology use and standardised charts have been used to improve patient safety. $[14,81]$ In a three-hospital study, the handover sheets were used as a structured communication tool to communicate patient clinical information effectively and accurately at handover time. [63] Although involving a barcode medication administration system increased the workload of nurses and pharmacists, it also increased patient medication safety by reducing medication errors at the ordering, transcribing and administration stages of the medication process. [66] The use of bedside barcode systems combined with an interprofessional team and onsite pharmacy consultation reduced the number of medication errors. [74] Two studies [66,74] used the barcode system as a form of structured communication to reduce the medication incidents and to improve patient safety. The first step to reduce or eliminate recognised errors is to enhance communication skills and better interactions between the healthcare team and the patient to improve patient safety. [73] The findings of these studies highlighted that using structured communication avoids preventable medication errors, which costs both patient and healthcare system. Most of the researchers agreed that structured communication can improve patient medication safety rate but there are limited studies that measured the reduction in medication errors when using structured communication.

\section{Medication management cycle}

In the drug distribution chain, [3] the breach of the seven 'rights' (right patient, right drug, right dose, right time, right route, right reason and right documentation) along with inter-professional communication, prescription errors accounted for $70 \%$ of medication errors. [14] Medication administration errors occur in one in every five medication dosages. [6] Three of the reviewed studies reported that communication failure leads to medication errors and is due to poor communication by multidisciplinary teams through the drug prescription and drug administration cycle, [65] inadequate communication as the responsible person's attention was drawn away from achieving the medication administration goal [68] and communication issues at every stage of the cycle, were evident as a leading cause of medication errors. [69] According to the medication management cycle [24] and these studies, $[65,68,69]$ the researchers argued that communicating effectively and working collaboratively are important factors of medication safety.

\section{Health professional communication education}

Health professionals realise that there is a need to pay greater attention to communication in the workplace. This requires healthcare professionals to be formally trained in communication skills. The theoretically-based two days communication skills training program for nurses enabled them to identify situations that warrant crucial conversations regarding to patient safety. [67]

Similarly, educating pharmacy students about communication and medication errors enables them to communicate effectively around various medication errors. [72] These two studies indicated that education on how to communicate effectively, as a part of the socio-cultural environment of the healthcare system, is important and necessary for all health professionals to reduce communication-based medication errors.

\section{Pharmacists and communication}

Pharmacists play a primary role in preventing medication errors. Pharmacists' daily practices involve communication pathways from the physician's order, transcribing it onto a label for the patient and making sure that the right medication and right dose matches the patient prescription. All of these steps are based on communication and with it comes the potential for medication errors. Pharmacists among other health professionals are the ones who indicated the importance of effective communication. [16, 82-84] The reviewed study explored the importance of medication communication between community pharmacies and different healthcare providers during transfers of care and this study explained that the lack of a standardised process for the receipt of information within the pharmacy was another related problem and the pharmacists felt that the consequences of poor communication could be fatal or lead to patient harm. [76] The roles of pharmacists are often assumed to be 'guardians' in ensuring that medication errors do not occur. [2]

Thus, from the pharmacist's perception, communication plays a key role in patient medication management and safety. In addition, the result of another study showed that the reactive medication communication between pharmacists and other health professionals, like nurses and doctors, has expanded the pharmacist's role, involving them in decision-making at the treatment level. [77] 


\section{Other findings of the SLR}

While the systematic review finding could be categorised into five main themes, other findings have emerged. Although the Chang and Mark [70] research indicated that there is no relationship between communication factors and medication error related factors, it did not define communication variables clearly. This study is in contrast with the 17 other studies, which highlight the relationship between communication and medication errors. Additionally, it could be argued that this study only measured communication with physicians and did not clarify the communication variable factors appropriately during the medication process use.

Thus, it could be suggested that there is a deficit in information about the measurement of the communication contributing factors during the drug distribution chain in this study.

In relation to the limitation of the included studies, eight of the studies did not mention any research limitation. [60-62, $65,66,69,73,74]$ Four studies could not be generalised due to their small sample size, participants' specific characteristics and measurement of the related factors. $[68,71,75,77]$ In contrast to earlier findings, however, there was no evidence of structured communication reducing medication errors in longitudinal studies. Additionally, in relation to the medication management cycle, a considerable number of studies discussed the structured communication between nurses and physicians, pharmacists and doctors and nurses, nurses and nurses, especially in handover time and the outcome of the structured communication on medication errors. [61,65, 67-69, 71,75,77]

Controversially, there have been no studies specifically targeting structured communication between pharmacists and other health professionals who are involved in the patient medication management cycle and the effect of structured verbal or non-verbal communication between pharmacists and other health professionals on medication errors. Furthermore, the majority of the studies were from the United States, United Kingdom and Canada while there were only two studies from Australia.

What has not been highlighted is that while there have been a number of studies that have emphasised structured communication (barcode, electronic resources, SBAR, etc.), no study has accurately quantified the reduction in medication errors by using one or more of these approaches. There has not been any attempt to identify the 'gold standard' that is: does one of those structured communication approaches have a greater impact on reducing medication errors than the other reported approaches?

\section{Limitations}

The limitation of this study considered the publication bias among the included studies, although the peer reviewed search strategy was applied. To offset this potential bias, two researchers, unrelated to the study, reviewed the work for consistency and completeness. Additionally, the limitation in the search strategy was considered as the search protocol might have overlooked some important studies. This study included all the qualitative, quantitative and mixed method studies that fulfilled the inclusion criteria and this can influence the choice of studies outcome. The inclusion criteria of studies into a review process may be influenced by knowledge of the results of the set of potential studies. Unpublished research was not included in this study, to reduce the potential of this influence.

The limitation of quality assessment and data extraction was reduced by the review by two independent researchers.

\section{Conclusion}

The outcomes of this study are instructive for health managers in several ways.

Firstly, the study demonstrates the considerable cost implication of poor clinical communication and medication error. A focused approach on inter professional communications could significantly reduce hospital costs and poor patient outcomes. Secondly, improving communication in relation to medication errors can provide organisations with measurable improvements in patient safety and quality.

The finding of this study provides a deeper understanding of the relationship between communication and medication errors and offers an agenda for future study. As a result of this systematic review, future research could include:

- Does the use of structured verbal communication, like SBAR, between pharmacists and other health professionals involved in the medication management cycle reduce the medication error rates?

- Future research, using a longitudinal study approach, could examine whether the implementation of structured communication reduces the medication error rates and improves patient medication safety.

- From the perspective of quality of care and patient safety, what is the quantifiable outcome (savings to the patient and healthcare system, reduced cost of treatments through reducing medication errors, cost of reduced morbidity and mortality) of using structured communication to reduce the number of medication errors? 
Overall, this SLR, with all its challenges and limitations, defines the relationship between communication and medication errors. Additionally, this study indicates the need for future longitudinal quantitative studies and qualitative research on the use of structured communication between health professionals and the reduction in medication errors.

\section{Competing interests}

The authors declare that they have no competing interests.

\section{References}

1. Durmus $\mathrm{SÇ}$, et al. Medical errors: an important indicator of quality of care and patient safety. Holistic Nursing Practice. 2013; 27(4):225-232.

2. Rattanarojsakul $\mathrm{P}$, Thawesaengskulthai N. A medication safety model: a case study in Thai hospital. Global Journal of Health Science. 2013;5(5): 89.

3. Guchelaar H-J, et al. Medication errors. Drugs. 2005; 65(13):1735-1746.

4. Kaushal R. et al. Adverse drug events in pediatric outpatients. Ambulatory Pediatrics. 2007;7(5):383-9.

5. Gandhi TK, et al. Adverse drug events in ambulatory care. The New England Journal of Medicine. 2003;348(16):1556-1564.

6. McBride-Henry K, Foureur M. Medication administration errors: understanding the issues. The Australian Journal of Advanced Nursing. 2006;23(3):33-41.

7. Berger BA. Communication skills for pharmacists: building relationships, improving patient care. American Pharmacists Association; 2005.

8. Christen C. Clinical pharmacy and medication safety. The Annals of Pharmacotherapy. 2006;40(11):2020-2021.

9. Stephens M. Hospital pharmacy. London: Pharmaceutical Press; 2003.

10. Ferner RE, Aronson JK. Clarification of terminology in medication errors. Drug Safety. 2006;29(11):1011-1022.

11. Dean B, et al. Causes of prescribing errors in hospital inpatients: a prospective study. The Lancet. 2002;359(9315):1373-1378.

12. Lesar TS, Briceland L, Stein DS. Factors related to errors in medication prescribing. JAMA. 1997;277(4):312-317.

13. Cina $J$, et al. How many hospital pharmacy medication dispensing errors go undetected? Joint Commission Journal on Quality and Patient Safety. 2006;32(2):73-80.

14. Velo GP, Minuz P. Medication errors: prescribing faults and prescription errors. British Journal of Clinical Pharmacology. 2009;67(6):624-628.

15. Clancy TR. Medication error prevention. Progress of initiatives. JONA's Healthcare Law, Ethics, and Regulation. 2004;6(1):3-12; quiz 13-4.

16. Creswick N, Westbrook JJ. Who do hospital physicians and nurses go to for advice about medications? A social network analysis and examination of prescribing error rates. Journal of Patient Safety. 2014:1.

17. Lewis $\mathrm{PJ}$, et al. Prevalence, incidence and nature of prescribing errors in hospital inpatients. Drug Safety. 2009;32(5):379-389.

18. Roughead EE, Semple SJ. Medication safety in acute care in Australia: where are we now? Part 1: a review of the extent and causes of medication problems 2002-2008. Australia and New Zealand Health Policy. 2009;6(1):18-18.
19. Safety and Quality Council. Second National Report on Patient safety, Improving Medication Safety. 2002. Available from: http:// www.safetyandquality.gov.au/wp-content/uploads/2012/12/ Second-National-Report-on-Patient-Safety-Improving-MedicationSafety.pdf.

20. Roughead L, Semple, S, Rosenfeld E. Medication Safety in Australia. 2013. Available from: https://safetyandquality.gov.au/wp-content/ uploads/2014/02/Literature-Review-Medication-Safety-inAustralia-2013.pdf.

21. Roughead EE, Lexchin J. Adverse drug events: counting is not enough, action is needed. Med J Aust. 2006;184(7):315.

22. Miller GC, Britt HC, Valenti L. Adverse drug events in general practice patients in Australia. Med J Aust.. 2006;184(7):321.

23. Runciman $W$, et al. Adverse drug events and medication errors in Australia. International Journal for Quality in Healthcare. 2003;15 Suppl 1(1):i49-I59.

24. Duguid M. Medication safety in Australia an overview. 2009. Available from: http://www.crepatientsafety.org.au/seminars/ medicationsafety/presentations/margaretduguid.pdf.

25. Carlton G, Blegen MA. Medication-related errors: a literature review of incidence and antecedents. Annual Review of Nursing Research. 2006; 24(1): 19-38.

26. Keers RN, et al. Prevalence and nature of medication administration errors in healthcare settings: a systematic review of direct observational evidence. Annals of Pharmacotherapy. 2013;47(2): p. 237-256.

27. Queensland Health. Patient Safety: From Learning to Action IV. Fourth Queensland Health Report on Clinical Incidents and Sentinel Events in the Queensland Public Health System 2008/09 C.f.H.I.P.s.a.q.i. service, Editor. 2011.

28. Government of Western Australia. WA Health Clincal Handover Policy. 2013. !36

29. Turkoski BB. Improving patient safety by improving medication communication. Orthopaedic Nursing. 2009;28(3):150-152.

30. Van der Kam W, et al. Effects of electronic communication between the GP and the pharmacist. The quality of medication data on admission and after discharge. Family Practice. 2001;18(6):605-609.

31. Thomas RK. Health communication. New York: Springer; 2006.

32. Berry D. Health communication. McGraw-Hill.; 2007.

33. Street Jr RL, et al. How does communication heal? Pathways linking clinician-patient communication to health outcomes. Patient Education and Counseling. 2009;74(3):295-301.

34. Interprofessional Education Collaborative Expert Panel. Core competencies for interprofessional collaborative practice: Report of an expert panel. 2011.

35. Marshall S, Harrison J, Flanagan B. The teaching of a structured tool improves the clarity and content of interprofessional clinical communication. Quality and Safety in Healthcare. 2009;18(2): 137-140.

36. Reeves S, Lewin S. Interprofessional collaboration in the hospital: strategies and meanings. Journal of Health Services Research and Policy. 2004;9(4):218-225.

37. Suter $\mathrm{E}$, et al. Role understanding and effective communication as core competencies for collaborative practice. Journal of Interprofessional Care. 2009;23(1):41-51.

38. Varpio L, et al. Interprofessional communication and medical error: a reframing of research questions and approaches. Academic Medicine. 2008;83(10):76-81.

39. Zwarenstein M, Goldman J, Reeves S. Interprofessional collaboration: effects of practice-based interventions on professional practice and healthcare outcomes. The Cochrane Database of Systematic Reviews. 2009; (3):CD000072. 
40. Australian Commission on Safety and Quality in Healthcare. Implementation toolkit for clinical handover improvement N.S.a.Q.H.S.S. (NSQHS), Editor. Sydney: ACSQHC; 2011.

41. The Joint Commission. Senital Event Data Root causes by event type, O.o.Q. Monitoring, Editor; 2013.

42. Conn LG, et al. Communication channels in general internal medicine: a description of baseline patterns for improved interprofessional collaboration. Qualitative Health Research. 2009;19(7):943-53.

43. Treher EN, Noah J. Interpersonal communication: challenges and solutions: strategies to improve organizational and individual communication. Laboratory Medicine. 2008;39(5):261-264.

44. Clinical Excellence Commission. Analysis of First year of IIMS Data: Annual Report 2005-2006. P.S.C.I.M.i. NSW, Editor; 2006.

45. NSW Health. Patient Safety and Clinical Quality Program.Third report on incident management in the NSW public health system 2005-2006. Sydney; NSW Health; 2006.

46. Victorian Department of Health. Building foundations to support patient safety: Annual Report of the 2008-09 Sentinel event program. Melbourne: Vic Health; 2009.

47. Hinchcliff R, et al. Analysis of Australian newspaper coverage of medication errors. International Journal for Quality in Healthcare. 2012; 24(1):1-8.

48. Queensland Health. Patient safety from learning to action. First Queensland Health report on clinical incidents and sentinel events. Brisbane: P.S. Centre; 2007.

49. Queensland Health. Patient Safety from learning to action II. Second Queensland Health report on clinical incidnets in the Queensland public health system 2006/7. Brisbane: P.S. Centre; 2008.

50. Pope BB, Rodzen L, Spross G. Raising the SBAR: how better communication improves patient outcomes. Nursing. 2013;38(3):41-43.

51. Rodgers KL. Using the SBAR communication technique to improve nursephysician phone communication: a pilot study. American Academy of Ambulatory Care Nursing. 2007;29(2):7.

52. Dunsford J. Structured communication: improving patient safety with SBAR. Nursing for Women's Health. 2009;13(5):384-390.

53. Haig KM, Sutton S, Whittington J. SBAR: a shared mental model for improving communication between clinicians. Joint Commission Journal on Quality and Patient Safety. 2006;32(3):167-175.

54. Trentham B, et al. SBAR: A Shared Structure for Team Communication, T.R. Institute, Editor. 2007.

55. Beckett $C D$, Kipnis G. Collaborative communication: integrating SBAR to improve quality/patient safety outcomes. Journal for Healthcare Qualit. 2009;31(5):19-28.

56. Powell SK. SBAR-It's not just another communication tool. Professional Case Management. 2007;12(4):195-196.

57. Thomas CM, Bertram E, Johnson D. The SBAR communication technique: teaching nursing students professional communication skills. Nurse Educator. 2009;34(4):176-180.

58. Greenfield D, et al. The standard of healthcare accreditation standards: a review of empirical research underpinning their development and impact. BMC Health Services Research. 2012;12(1):329.

59. University of York. Systematic reviews: CRD's guidance for undertaking reviews in healthcare. York: CRD, University of York; 2009.

60. Frydenberg K, Brekke M. Poor communication on patients medication across healthcare levels leads to potentially harmful medication errors. Scandinavian Journal of Primary Healthcare. 2012;30(4):234-240.
61. Manno M, et al. Patient-safety survey report. Nursing. 2006; 36(5):54-63

62. Croskerry $P$, et al. Profiles in patient safety: medication errors in the emergency department. Academic Emergency Medicine. 2004; 11(3): 289-299.

63. Chaboyer W, McMurray A, Wallis M. Bedside nursing handover: a case study. International Journal of Nursing Practice. 2010; 16(1):27-34

64. Manojlovich M, DeCicco B. Healthy work environments, nursephysician communication, and patients' outcomes. American Journal of Critical Care. 2007;16(6):536-543.

65. Birch L, Culshaw A. Drug error in maternity care: a multiprofessional issue. British Journal of Midwifery. 2003;11(3):173-175.

66. Ross J. Collaboration -- integrating nursing, pharmacy and information technology into a barcode medication administration system implementation. CARING Newsletter. 2008;23(1):1.

67. Saxton R. Communication skills training to address disruptive physician behavior. AORN Journal. 2012;95(5):602-611.

68. Pape TM. Applying airline safety practices to medication administration. Medsurg Nursing. 2003;12(2):77-93; quiz 94.

69. Vogelsmeier A, Scott-Cawiezell J, Zellmer D. Barriers to safe medication administration in the nursing home-exploring staff perceptions and concerns about the medication use process. Journal of Gerontological Nursing. 2007;33(4):5-12.

70. Chang YK, Mark BA. Antecedents of severe and nonsevere medication errors. Journal of Nursing Scholarship. 2009, 41(1):70-78

71. McBride-Henry K, Foureur M. A secondary care nursing perspective on medication administration safety. Journal of Advanced Nursing. 2007; 60(1): 58-66.

72. Noland CM, Rickles NM. Reflection and analysis of how pharmacy students learn to communicate about medication errors. Health Communication. 2009;24(4):351-360.

73. Benjamin DM. Reducing medication errors and increasing patient safety: case studies in clinical pharmacology. The Journal of Clinical Pharmacology. 2003;43(7):768-783.

74. Cochran GL, Haynatzki G. Comparison of medication safety effectiveness among nine critical access hospitals. American Journal of Health-System Pharmacy. 2013;70(24):2218-2224.

75. Rubin G, et al. Errors in general practice: development of an error classification and pilot study of a method for detecting errors. Qual Saf Healthc. 2003;12(6):443-447.

76. Urban $\mathrm{R}$, et al. Communicating medication changes to community pharmacy post-discharge: the good, the bad, and the improvements. International Journal of Clinical Pharmacy. 2013;35(5):813-820.

77. Sascha Rixon SB, Williams A, Liew D, Manias E. Pharmacists' Interprofessional communication about medications in specialty hospital settings. Routledge Taylor \& Francis Group. 2015;30(11).

78. Thomas J, Harden A. Methods for the thematic synthesis of qualitative research in systematic reviews. BMC Medical Research Methodology. 2008;8(1):45.

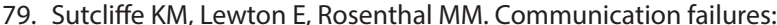
an insidious contributor to medical mishaps. Academic Medicine. 2004; 79(2): 186-194.

80. Richards HM, Schwartz LJ. Ethics of qualitative research: are there special issues for health services research? Family Practice. 2002; 19(2):135-139.

81. Catalano K, Fickenscher K. Complying with the 2008 national patient safety goals. AORN Journal. 2008;87(3):547-556 
82. Callen J, McIntosh J, Li J. Accuracy of medication documentation in hospital discharge summaries: a retrospective analysis of medication transcription errors in manual and electronic discharge summaries. International Journal of Medical Informatics. 2010;79(1):58-64.

83. Gallagher RM, Gallagher HC. Improving the working relationship between doctors and pharmacists: is inter-professional education the answer? Advances in Health Sciences Education: Theory and Practice. 2012; 17(2):47-257.

84. Paluck EC, et al. Assessment of communication barriers in community pharmacies. Evaluation and the Health Professions. 2003;26(4):380-403. 